\title{
Primary production in the Sulu Sea
}

\author{
IAN S F JONES \\ Ocean Technology Group, J05 University of Sydney, NSW 2006, Australia \\ email: otg@otg.usyd.edu.au \\ Also: Visiting Scientist, CRISP, National University of Singapore.
}

The Sulu Sea, located between Borneo and the Philippines, is separated from the surrounding ocean by two chains of islands. There are no passages below $500 \mathrm{~m}$ depth and the basin, which at the deepest is $5,000 \mathrm{~m}$, is filled with warm low oxygen water.

The near surface chlorophyll concentration has been examined with the aid of ocean colour sensors on board satellites. Direct comparisons between a field observation of chlorophyll and its remotely sensed values from OCTS (Ocean Colour Temperature Scanner) are found to be in satisfactory agreement. An 8-month time series of chlorophyll near the centre of the Sulu Sea has been used to show that the chlorophyll level is significantly higher than the level in the adjacent South China Sea. This was most pronounced at the period of change between the monsoons. The greater primary productivity may provide the explanation for the higher deposition rate of carbon in the Sulu Sea.

Although the Sulu Sea is more productive than the adjacent South China Sea, the central area can still be classified as a desert. Estimates of the new primary production in the central Sulu Sea seem to be just sufficient to support the current fishery.

\section{Introduction}

The Sulu is a deep ocean basin isolated from the surrounding ocean by a chain of islands. Mindoro Strait, a channel of $420 \mathrm{~m}$ depth, connects the Sulu Sea with the South China Sea. Waters below this depth are uniform in properties and extend to $5000 \mathrm{~m}$ depth. For long the stronghold of the fierce Moro pirates, the Sulu Sea is a little-studied region of the world's oceans. It has been suggested by Kuehl et al (1993) that the carbon sediment deposition rate in the centre of the Sulu Sea is 2-3 times that of the South China Sea. As there was no evidence that the surface waters of the Sulu Sea were more productive than the nearby South China Sea, Kuehl et al (1993) left unresolved the question of why more carbon has been deposited in the Sulu Sea. New ocean colour satellites have provided the tools to look at primary production in regions poorly surveyed by in situ measure- ments. This paper looks at an 8-month time series of chlorophyll $a$ determined from the OCTS sensor for two points towards the centre of the Sulu Sea and another in the neighbouring South China Sea. The sea floor was cored at these sites by Kuehl et al (1993).

Since the Sulu Sea is a closed basin below $420 \mathrm{~m}$ (Kuehl et al 1993), the temperature of the deep water is uniformly near $10^{\circ} \mathrm{C}$, (Tizard et al 1884) the phosphate is about 3 microgram-atoms/litre while the nitrate level is 35 microgram-atoms/litre. With dimensions of $600 \mathrm{~km}$ by $400 \mathrm{~km}$ the Sulu Sea represents a store of about 200 Mtonnes of $\mathrm{N}$ and 40 Mtonnes of $\mathrm{P}$.

The flow of surface water into the Sulu Sea is restricted and it has been suggested that there is a flow from the South China Sea into the Sulu Sea during late summer and in the opposite direction in late winter in response

Keywords. Oceanography; remote sensing; primary production; Sulu Sea. 


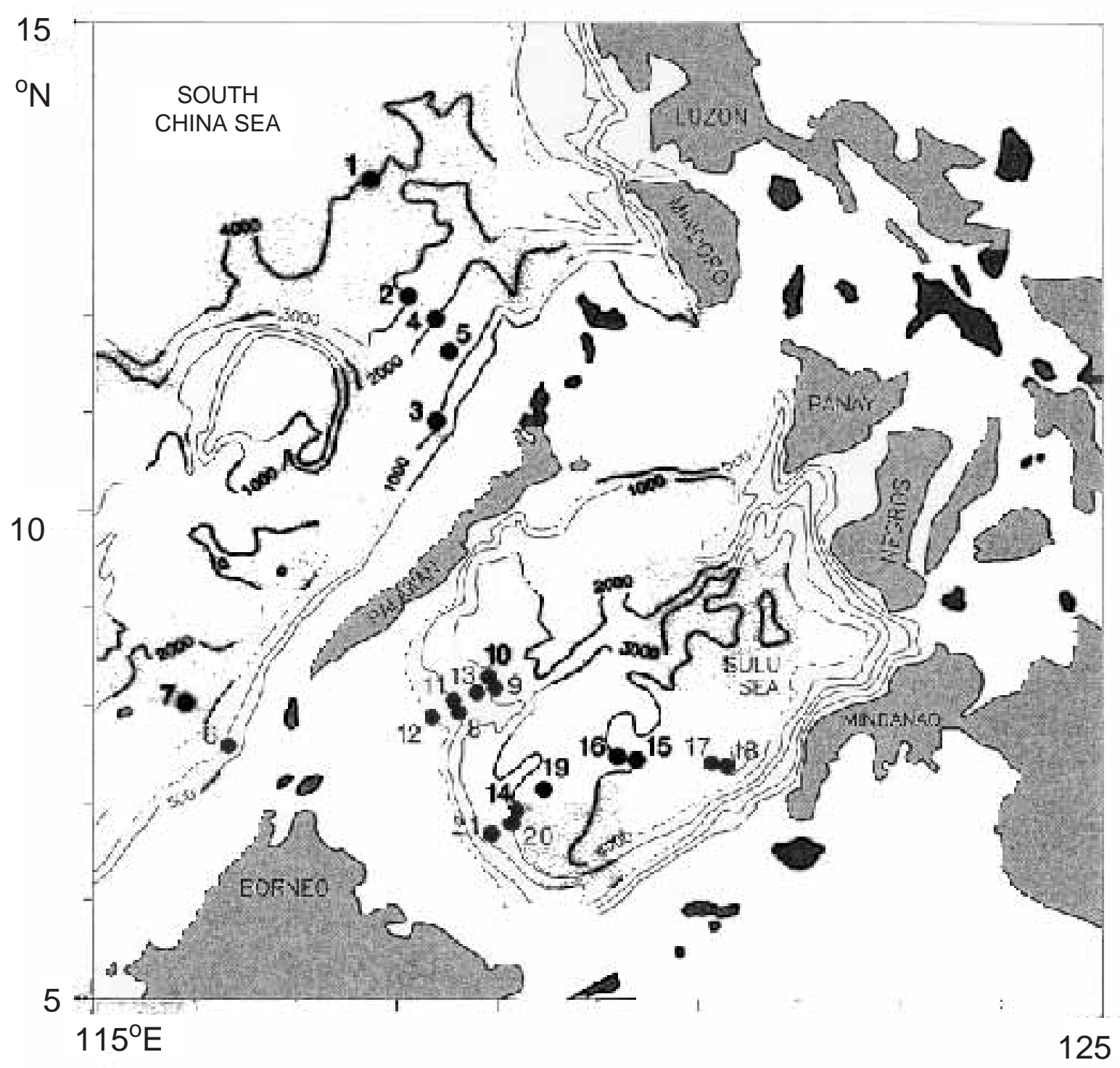

Figure 1. Sulu Sea showing sediment sites. The square dot is the site for in situ calibration of the satellite information. Depth contours in meters. After Kuehl et al (1993).

to monsoon wind forcing. Numerical modelling by Metzger and Hurlburt (1996) suggests that the upper water has a residence time of order one year, but does not support a reversing flow.

The relatively closed nature of the Sulu Sea and the simple administrative arrangement of it being within the EEZ of just two countries led Young and Gunaratnam (1996) to suggest that the Sulu Sea might be a suitable area in which to increase the sustainable fish catch by enhancing the new primary production. They pointed out that primary production was limited over most of the Sulu Sea and could be increased by providing the nutrients that are in short supply in the photic zone of the ocean.

\section{Sediment records}

Bertrand et al (1991) gave sediment deposition rates from ODP (Ocean Drilling Program) site 768. Kuehl et al (1993) used carbon 14 to date the box cores they collected at the locations shown in figure 1 . They found that the carbon sediment deposition rate is $2-3$ times that of the South China Sea.

The sedimentation rates deduced from the cores are reproduced in table 1 .

\section{OCTS Sensor}

By measuring ocean colour, the concentration of phytoplankton can be estimated in what is called case 1 waters. The bands of light used are discussed 
Table 1. Core information.

\begin{tabular}{lcc}
\hline Location & $\begin{array}{c}\text { Depth } \\
\text { M }\end{array}$ & $\begin{array}{c}\text { Sedimentation rate } \\
\mathrm{cm} \mathrm{kyr}^{-1}\end{array}$ \\
\hline Sulu Sea & & \\
BC8 & 1005 & 12.32 \\
BC9 & 1995 & 5.05 \\
BC20 & 3000 & 8.27 \\
BC16 & 4000 & 5.72 \\
South China Sea & & \\
BC3 & 1095 & 2.95 \\
BC4 & 2150 & 2.99 \\
BC2 & 2950 & 2.73 \\
\hline
\end{tabular}

in Jones et al (1993). Only case 1 waters are considered in this study. Figure 2 shows a chlorophyll map that is a composite of data from one week. Processing of the water leaving radiances was by the version 3 algorithm. Data were averaged over nine kilometers of a thinned number of high resolution pixels to produce GAC data files.

The Hakuho Maru Cruise KH-96-5 found that at a station over the deepest portion of the Sulu Sea $\left(8.8^{\circ} \mathrm{N}\right.$ and $121.8^{\circ} \mathrm{E}$, marked in figure 1$)$ the surface cholorophyll was about $0.28 \mathrm{mg} / \mathrm{m}^{3}$ at the surface and $0.41 \mathrm{mg} / \mathrm{m}^{3}$ at $36 \mathrm{~m}$ depth on the 25 th December 1996. This compares well with the satellite which for this location registered $0.33 \mathrm{mg} / \mathrm{m}^{3}$ on 22nd December (2 days before) and $0.5 \mathrm{mg} / \mathrm{m}^{3}$ on 29th December (4 days later). Clouds covered the area for the satellite passes between these dates.

Where does the nutrient come from to sustain the growth of phytoplankton? The inflow of nutrients to the Sulu Sea is not large. The winds, that at other sites provide erosion of the nutricline to mix rich deeper waters, are light.

\section{Results}

The time series of chlorophyll $a$ at locations 4,9 and 16 shown in figure 1 were prepared by using a cloud free pixel within a radius of $15 \mathrm{~km}$ of the core site. On some occasions there were no cloud free pixels and this produced the gaps in the time series. The region in the centre of the Sulu Sea shows a general level of chlorophyll of less than $0.2 \mathrm{mg} / \mathrm{m}^{3}$ except for three weeks where the levels approached $1 \mathrm{mg} / \mathrm{m}^{3}$. This mild bloom occurred over most of the Sulu Sea that was cloud free. There was no such bloom in the South China Sea. Clouds obscured the locations studied during weeks 9 and 10 . A region just a little more than $15 \mathrm{~km}$ from site 9 is shown for week 10 to avoid cloud contamination.

The increase of phytoplankton in the central Sulu Sea occurred at the same time as the change in the monsoon in February. Climatological wind records (1961-1995) from the Island Zamboanga del Sur $\left(6.9^{\circ} \mathrm{N}, 122.07^{\circ} \mathrm{E}\right)$ that forms part of the south eastern boundary of the Sulu Sea, show low wind speeds typically below $4 \mathrm{~ms}^{-1}$. However they show a change in wind direction in February from NE to westerly. Is it the major shift in wind direction that provides additional nutrients to the photic zone and supports the increase in primary production?

Since the OCTS data are only for 8 months we cannot be confident that the differences in phytoplankton activity in and out of the Sulu Sea is repeated each year. With new data coming from SeaWiFS and other ocean colour sensors it will soon be possible to be more confident about primary production in the region.

\section{Primary production}

Primary production by phytoplankton forms the base of the food chain on which the Sulu Sea fishery depends. In turn fisheries provide the people of the Philippines $53 \%$ of their animal protein while Malaysia, the other country with an EEZ in the Sulu Sea, gets $23 \%$ of its protein from the sea, FAO (1996). Local fishermen caught about 200,000 tonnes of fish from the Sulu Sea in 1995. If we assume that the catch is no more than $25 \%$ per year of the standing stock, to avoid the fisheries collapsing, the fish production of the Sulu Sea must be of the order of $800,000 \mathrm{t} / \mathrm{yr}$.

By dividing the fish production by the areas of the Sulu Sea we find that it is about $7 \mathrm{~g} \mathrm{~m}^{-2} \mathrm{yr}^{-1}$. This of course is an average over the Sea and in reality there is high production figures near the shore and lower in the centre. Iverson (1990) provided a relationship between fish production and primary production. He suggested that $120 \mathrm{~g} \mathrm{~cm}^{-2} \mathrm{yr}^{-1}$ of phytoplankton production will support this level of fish production. It implies a transfer efficiency between trophic levels of about $15 \%$.

The OCTS data suggest that typical chlorophyll concentrations in the centre of the Sulu Sea are about $0.2 \mathrm{mg} / \mathrm{m}^{3}$. Using a so-called depth integrated model of the type described in Behrenfeld and Falkowshi (1997) the primary production associated with this level of chlorophyll would be $\sim 273 \mathrm{~g} \mathrm{~cm}^{-2} \mathrm{yr}^{-1}$. If we assume an export of carbon from the mixed layer of $20 \%$, e.g., Iverson (1990), this is an export of carbon of $54 \mathrm{~g} \mathrm{~m}^{-2} \mathrm{yr}^{-1}$. As in other oligotrophic oceans, we believe the level of organic carbon is controlled by the limitation in nutrients. Nutrients have been observed to be low in the central Sulu Sea. For example in the Hakuho Maru cruise discussed above, the nitrate 


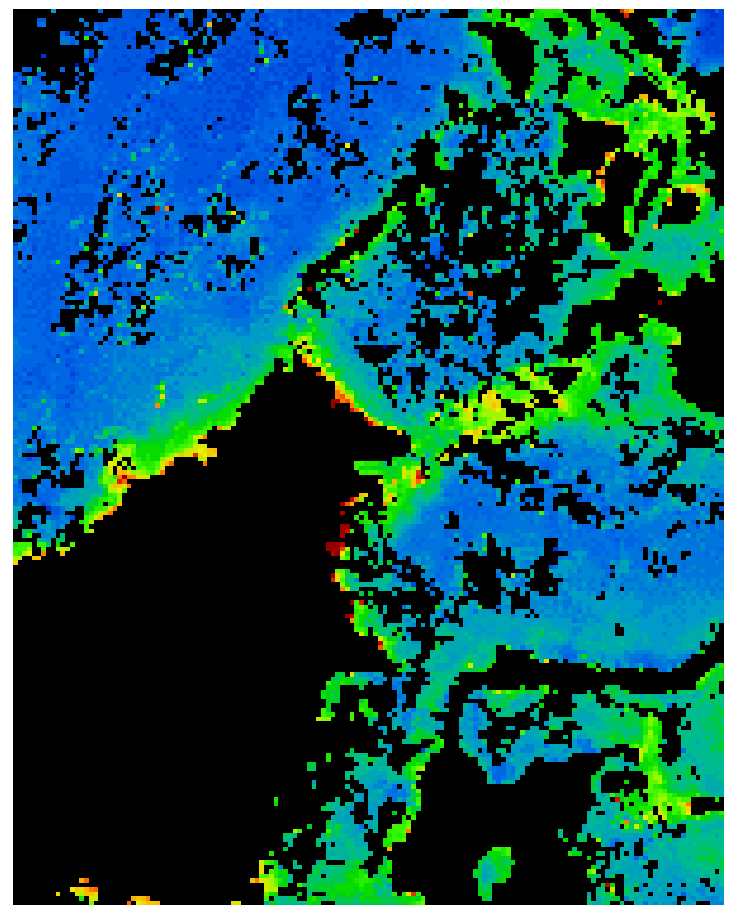

(a)

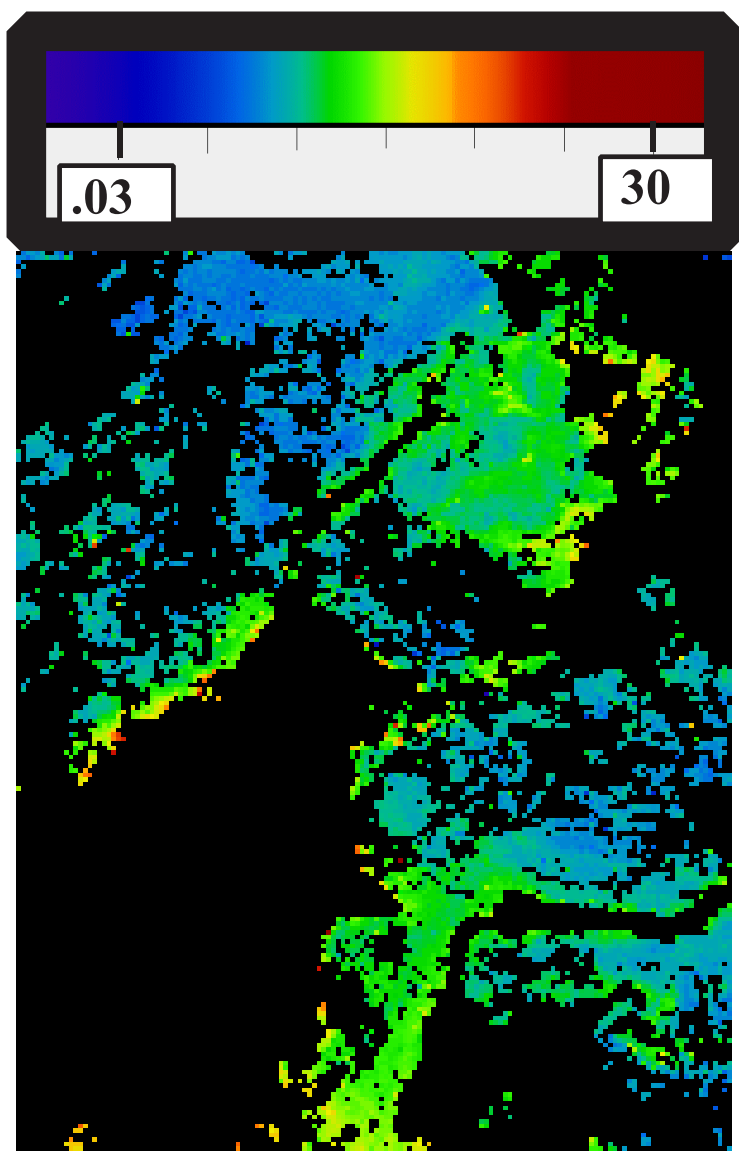

(b)

(C)NASDA

Figure 2. Two scenes of the Sulu Sea (a) showing "typical" phytoplankton level over most of the Sulu Sea during week 19970601. (b) The image 19970126 (the week starting 26th January) shows increased phytoplankton activity in the Sulu Sea but general low levels of chlorophyll in the South China Sea. Colour bar units $\mathrm{mg} / \mathrm{m}^{3}$ of chlorophyll. 


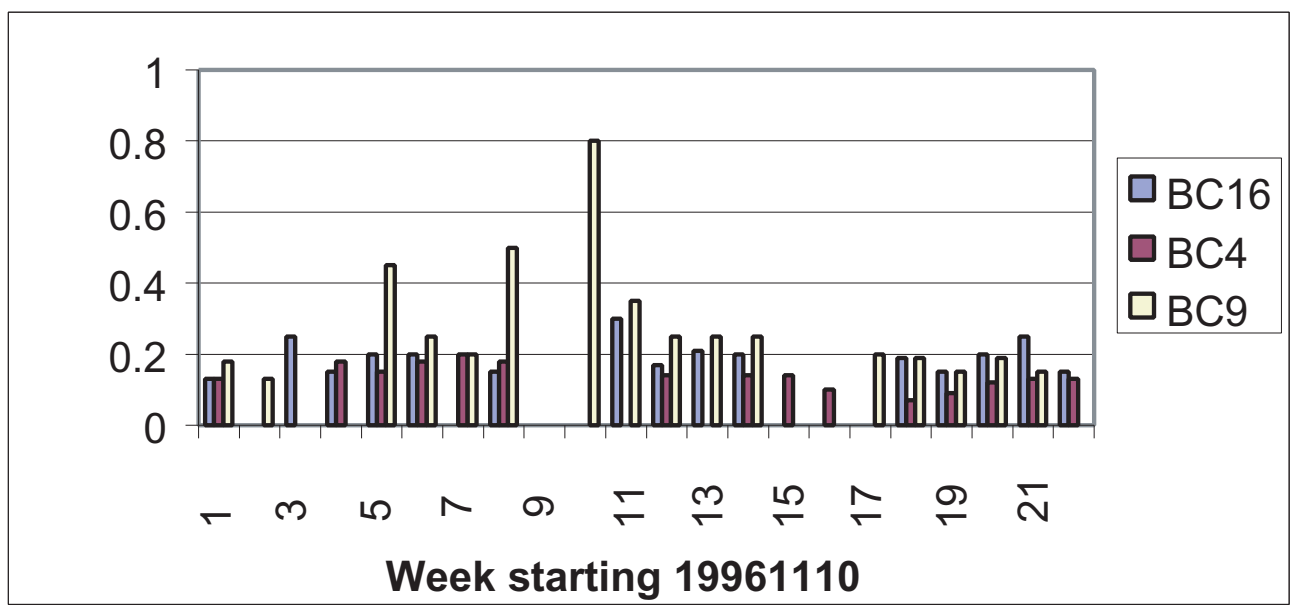

Figure 3. Chlorophyll levels detected by OCTS for locations BC9 and BC16 within the Sulu Sea. Location BC4 is in the South China Sea. Enhanced productivity in the Sulu Sea is seen around week 10.

level in the surface water was less than $0.03 \mu \mathrm{M}$ $\left(10^{-6}\right.$ g-atoms $\left./ \mathrm{l}\right)$ with a $50 \mathrm{~m}$ deep mixed layer.

Young and Gunaratnam (1996) suggested that new additional nutrients might be supplied to the Sulu Sea in order to increase the fish resources available to people of the Philippines and Malaysia as well as reduce atmospheric $\mathrm{CO}_{2}$. This interesting concept is now known as Ocean Nourishment and examined in Jones (2002).

\section{Conclusion}

It seems that the increased sedimentation rate of carbon on the floor of the Sulu Sea over that of the adjacent South China Sea may be due to episodic higher phytoplankton activity in the Sulu Sea as a result of the change of prevailing wind patterns between the two monsoons.

The current fish catches from the Sulu Sea appear to be limited by or close to being limited by primary production. It will take an increase of primary production for the Sulu Sea to provide more of the protein needed by the people of the Philippines.

\section{Acknowledgements}

This study was carried out while the author was a visitor to EORC/NASDA in Tokyo. Professor Y Toba encouraged the author to consider the Sulu Sea and discussed the ideas in this paper with him.
This paper was presented at PORSEC 2000 and revised at CRISP of the National University of Singapore.

\section{References}

Behrenfeld M J and Falkowshi P G 1997 A consumer's guide to phytoplankton primary productivity models; Limnol. Oceanogr. 42 1479-1491

Bertrand P, Berner U and Lallier-Verges E 1991 Organic sedimentation in Celebes and Sulu Basins (eds) E A Silver, C Rangin, M T von Breymann et al. Proceedings of the Ocean Drilling Program, Scientific Results, 124, $217-223$

FAO 1996 The Sixth World Food Survey Food, Rome, pp 153. ISBN 9251038376.

Iverson R L 1990 Control of marine fish production; Limnology and Oceanography 35 1593-1604

Jones I S F 2002 Climate stabilisation and food security. In: Handbook of Microalgae Culture, (ed) A Richmond, Blackwells (in press)

Jones I S F, Sugimori Y and Stewart R W 1993 Satellite remote sensing of the oceanic environment; Seibutsu Kenkyusha, Tokyo. ISBN 4-915342-10-7

Kuehl S A, Fuglseth T J and Thunell R C 1993 Sediment mixing and accumulation rates in the Sulu and South China Sea; Mar. Geol. 111, 15-35

Metzger E J and Hurlburt H E 1996 Coupled dynamics of the South China Sea, the Sulu Sea and Pacific Ocean; $J$. Geophysics Res. 101 12,331-12,352

Tizard T H, Moseley H N, Buchanan J Y and Murray J 1884 Narrative of the cruise of HMAS Challenger, with a general account of the scientific results of the expedition (London: HMSO)

Young H E and Gunaratnam M K 1996 In search of sustainable regional fisheries; The Maritime Institute of Malaysia Bulletin 3 11-13 [ISBN 1394 5947] 